\title{
REDISAIN INSTALASI PENGOLAHAN AIR LIMBAH (IPAL) RUMAH SAKIT UMUM DAERAH (RSUD) TIMIKA, PAPUA
}

\author{
Setiyono dan P. Nugro Rahardjo \\ Pusat Teknologi Lingkungan, BPPTeknologi \\ JI. MH. Thamrin No. 8 Jakarta Pusat
}

\begin{abstract}
Hospital is playing an important role in serving people who need to get health. On the other hand its occurrence causes some problems as well. One of them is the infectious wastewaters which are potential to cause a dangerous effect for human life. A lot of hospitals in Indonesia do not have the proper wastewater treatment plant yet. The local hospital of County Timika has already had a wastewater treatment plant (WWTP), but until now the capacity of the unit can not fulfil the required level of environmental standard yet. One of the problems is the technically improper treatment processes. To solve the problems, the WWTP must be redesigned and modifief by using a combination technique of anaerobik and aerobic biofilter treatment processes. The newly proposed design process of WWTP for the local hospital in TImika has already prepared to be applied.
\end{abstract}

Keywords : Medical Wastewater Treatment Process, anerobic/aerobic biofilter

\section{PENDAHULUAN}

\subsection{Latar Belakang}

Rumah sakit merupakan fasilitas sosial yang tak mungkin dapat dipisahkan dengan masyarakat, dan keberadaannya sangat diharapkan oleh masyarakat, karena sebagai manusia atau masyarakat tentu menginginkan agar kesehatannya tetap terjaga. Dalam aktivitasnya, rumah sakit banyak menghasilkan limbah cair yang banyak mengandung bakteri/virus, serta mikro-organisme patogen yang berasal dari para pasien, sehingga air limbah yang berasal dari limbah rumah sakit merupakan salah satu sumber pencemaran air yang sangat potensial. Oleh karena potensi dampak air limbah rumah sakit terhadap kesehatan masyarakat sangat besar, maka setiap rumah sakit diharuskan mengolah air limbahnya sampai memenuhi persyaratan standar yang berlaku.

Dengan adanya peraturan yang mengharuskan bahwa setiap rumah sakit harus mengolah air limbah sampai standar yang diijinkan, maka kebutuhan akan teknologi pengolahan air limbah rumah sakit khususnya yang murah dan hasilnya baik perlu dikembangkan. Hal ini mengingat bahwa kendala yang paling banyak dijumpai yakni teknologi yang ada saat ini masih cukup mahal, sedangkan di lain pihak dana yang tersedia untuk membangun unit alat pengolah air limbah tersebut sangat terbatas. Untuk mengatasi hal tersebut perlu dikembangkan teknologi pengolahan air limbah rumah sakit yang murah, mudah operasinya serta memenuhi standar yang berlaku.

Pusat Teknologi Lingkungan (PTL) BPPT, merupakan salah satu instansi yang telah berhasil mengembangkan teknologi pengolahan air limbah yang cocok diterapkan di rumah sakit untuk skala kecil dan menengah. Teknologi tersebut sampai saat ini sudah banyak diterapkan di berbagai rumah sakit dan puskesmas. Dari hasil pemantauan sampai saat ini IPAL yang sudah dibangun tersebut dapat beroperasi dengan baik dan dapat mengatasi kendala-kendala yang ada seperti yang tersebut di atas. Teknologi pengolahan air limbah rumah sakit yang berhasil dikembangkan tersebut menggunakan teknologi biofilter dengan menggunakan proses an-aerobik yang dikombinasikan dengan proses aerobik. Jenis biofilter yang dikembangkan juga merupakan hasil pengembangan para peneliti BPPT, yaitu berupa biofilter tipe sarang tawon ${ }^{(5)}$.

\subsection{Permasalahan}

RSUD Timika saat ini sudah mempunyai satu IPAL dan sarana jaringan pengumpul limbah, namun unit tersebut tidak dapat dioperasikan. Untuk mengetahui penyebab dari tidak berfungsinya sarana tersebut, maka telah dilakukan evaluasi. Hasil evaluasi ini, akan digunakan sebagai dasar untuk meredisain IPAL dan sarana pengumpulan limbah tersebut, agar RSUD Timika nantinya dapat memililki sarana pengelolaan limbah cair yang berfungsi dengan baik. 


\subsection{Tujuan dan Sasaran} adalah :

Tujuan dan sasaran dari kegiatan ini

- Mengevaluasi IPAL dan sistem pengelolaan air limbah RSUD Timika saat ini.

- Memberikan rekomendasi perbaikan sistem.

- Meredisain IPAL dan sarana pengumpulan limbah cair.

\subsection{Metodologi}

Metodologi pelaksanaan kegiatan ini adalah sebagai berikut:

- Survai lapangan.

- Observasi lapangan dan pengambilan datadata sekunder.

- Pengumpulan data, dengan target mendapatkan data-data sebagai berikut:

a. Peta lokasi RSUD.

b. Peta pengelolaan air (existing).

c. Jumlah pemakaian air.

d. Peta penyebaran sumber limbah.

- Perencanaan disain teknis sistem pengolahan air limbah.

- Pengolahan data sekunder dan data primer dengan bantuan perangkat lunak basis data dan statistik kemudian hasilnya dianalisa dan dibahas.

\subsection{Hasil Yang Diharapkan}

Hasil yang diharapkan dari pekerjaan ini adalah sebagai berikut :

1. Diperolehnya data tentang sebaran sumber buangan limbah cair di area RSUD.

2. Diperolehnya gambaran tentang rencana pengelolaan limbah cair yang baru.

3. Diperoleh satu disain perencanaan pengelolaan dan pengolahan limbah cair.

\section{HASIL DAN PEMBAHASAN}

\subsection{Sumber Limbah Cair RSUD}

Sumber limbah cair RSUD Timika terdiri dari limbah cair non infeksius, limbah cair infeksius dan limbah radio aktif. Limbah cair infeksius berasal dari :

a. Poliklinik.

b. Pelayanan perawatan pasien berupa limbah cair dari kamar mandi dan pencucian peralatan yang dipakai.

c. Laboratorium klinik, air limbah dari pencucian wadah-wadah urine, darah, serum, serta sisa-sisa reagensia yang telah terukur.

d. Ruang isolasi.

e. Ruang operasi.

f. Ruang persalinan. g. Instalasi farmasi.

h. Laundry.

Limbah cair non infeksius berasal dari :

a. Ruang administraasi.

b. Dapur dan kantin, limbah cair berasal dari pencucian alat makan, alat masak dan dari bahan makanan itu sendiri.

c. Kegiatan kebersihan setiap ruangan.

\subsection{Karakteristik Limbah Cair Rumah Sakit}

Secara umum kualitas air limbah rumah sakit tidak jauh berbeda, karena jenis kegiatan serta standar pemakaian air secara umum juga sama. Berdasarkan hasil dari berbagai penelitian, limbah rumah sakit mempunyai kualitas konsentrasi senyawa pencemar sangat bervariasi antara BOD 31,52 - 675,33 mg/l, ammonia 10,79 - 158,73 mg/l dan deterjen (MBAS) 1,66 - 9,79 mg/l. Hal ini mungkin disebabkan karena sumber air limbah juga bervarisi, sehingga faktor waktu dan metode pengambilan contoh sangat mempengaruhi besarnya konsentrasi. Secara lengkap karakteristik air limbah rumah sakit dapat dilihat pada Tabel $1^{(1)}$.

Tabel 1 . Karakteristik Air Limbah Rumah Sakit Di Daerah Jakarta

\begin{tabular}{|c|c|c|c|c|}
\hline No & PARAMETER & MINIMUM & MAKSIMUM & $\begin{array}{l}\text { RATA- } \\
\text { RATA }\end{array}$ \\
\hline 1 & BOD - mg/l & 31,52 & 675,33 & 353,43 \\
\hline 2 & COD - mg/l & 46,62 & 1183,4 & 615,01 \\
\hline 3 & $\begin{array}{l}\text { Angka Permanganat } \\
\left(\mathrm{KMnO}_{4}\right)-\mathrm{mg} / \mathrm{l}\end{array}$ & 69,84 & 739,56 & 404,7 \\
\hline 4 & $\begin{array}{l}\text { Ammoniak }\left(\mathrm{NH}_{3}\right) \text { - } \\
\mathrm{mg} / \mathrm{l}\end{array}$ & 10,79 & 158,73 & 84,76 \\
\hline 5 & Nitrit $\left(\mathrm{NO}_{2}{ }^{-}\right)-\mathrm{mg} / \mathrm{l}$ & 0,013 & 0,274 & 0,1435 \\
\hline 6 & Nitrat $\left(\mathrm{NO}_{3}^{-}\right)-\mathrm{mg} / \mathrm{l}$ & 2,25 & 8,91 & 5,58 \\
\hline 7 & Khlorida (Cl) - mg/l & 29,74 & 103,73 & 66,735 \\
\hline 8 & Sulfat $\left(\mathrm{SO}_{4}^{-}\right)-\mathrm{mg} / \mathrm{l}$ & 81,3 & 120,6 & 100,96 \\
\hline 9 & $\mathrm{pH}$ & 4,92 & 8,99 & 6,96 \\
\hline 10 & $\begin{array}{l}\text { Zat padat } \\
\text { tersuspensi (SS) } \\
\text { mg/l }\end{array}$ & 27,5 & 211 & 119,25 \\
\hline 11 & $\begin{array}{l}\text { Deterjen (MBAS) - } \\
\mathrm{mg} / \mathrm{l}\end{array}$ & 1,66 & 9,79 & 5,725 \\
\hline 12 & Minyal/lemak - mg/l & 1 & 125 & 63 \\
\hline 13 & $\begin{array}{l}\text { Cadmium }(\mathrm{Cd}) \text { - } \\
\mathrm{mg} / \mathrm{l}\end{array}$ & Ttd & 0,016 & 0,008 \\
\hline 14 & Timbal (Pb) & 0,002 & 0,04 & 0,021 \\
\hline 15 & $\begin{array}{l}\text { Tembaga (Cu) - } \\
\mathrm{mg} / \mathrm{l}\end{array}$ & Ttd & 0,49 & 0,245 \\
\hline 16 & Besi (Fe) - mg/l & 0,19 & 70 & 35,1 \\
\hline 17 & $\begin{array}{l}\text { Warna - (Skala Pt- } \\
\text { Co) }\end{array}$ & 31 & 150 & 76 \\
\hline 18 & Phenol - mg/l & 0,04 & 0,63 & 0,335 \\
\hline
\end{tabular}

Sumber : PD PAL JAYA 1995.

\subsection{Baku Mutu Limbah Cair Rumah Sakit}

Baku mutu air limbah rumah sakit adalah ukuran batas atau kadar unsur pencemar dan atau jumlah unsur pencemar yang ditenggang 
keberadaannya dalam air limbah rumah sakit yang akan dibuang atau dilepas ke air permukaan. Jadi semua air limbah rumah sakit sebelum dibuang ke perairan/saluran umum harus diolah terlebih dahulu sampai memenuhi baku mutu seperti tersebut. Sesuai dengan keputusan Meneg Lingkungan Hidup Republik Indonesia No. Kep-58/MENLH/12/1995 tentang Baku Mutu Limbah Cair bagi kegiatan rumah sakit, maka semua rumah sakit yang menghasilkan limbah harus mengolah limbahnya sampai memenuhi baku mutu yang berlaku sesuai dengan keputusan menteri tersebut (lihat Tabel 2) ${ }^{(3)}$.

Tabel 2. Lampiran Kep. Meneg LH No. KEP - 58/MENLH/12/1995, tentang Baku Mutu Limbah Cair Kegiatan RumahSakit Tanggal 12 Desember $1995^{(3)}$

\begin{tabular}{|c|c|}
\hline Parameter & Kadar Max. (mg/l) \\
\hline \multicolumn{2}{|l|}{ FISIKA } \\
\hline Suhu & $30^{\circ} \mathrm{C}$ \\
\hline \multicolumn{2}{|l|}{ KIMIA } \\
\hline $\mathrm{pH}$ & $6-9$ \\
\hline $\mathrm{BOD}_{5}$ & $30 \mathrm{Mg} / \mathrm{L}$ \\
\hline COD & $80 \mathrm{Mg} / \mathrm{L}$ \\
\hline TSS & $30 \mathrm{Mg} / \mathrm{L}$ \\
\hline $\mathrm{NH}_{3, \text { Bebas }}$ & $0,1 \mathrm{Mg} / \mathrm{L}$ \\
\hline $\mathrm{PO}_{4}$ & $2 \mathrm{Mg} / \mathrm{L}$ \\
\hline \multicolumn{2}{|l|}{ MIKROBIOLOGI } \\
\hline $\begin{array}{r}\text { MPN - Kuman } \\
\text { golongan koli }\end{array}$ & 10.00 \\
\hline
\end{tabular}

\subsection{Sistem Pengumpulan Limbah Cair di RSUD Timika Saat Ini}

RSUD Timika saat ini telah dilengkapi dengan sarana jaringan pengumpulan limbah. Sistem yang digunakan adalah seperti terlihat pada Gambar 1 dan 2 berikut ini.

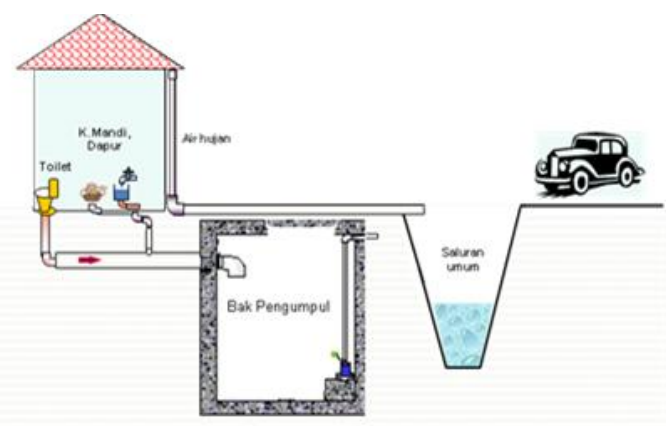

Gambar 1. Bak Pengumpul Limbah Cair di RSUD Timika

Keterangan :

- Semua limbah yang dihasilkan (feses, air dari kamar mandi, air dari dapur dIl) tercampur menjadi satu dan dikumpulkan dalam bak pengumpul kemudian dipompa menuju IPAL.

- Bak pengumpul yang ada hanya satu ruang, tidak ada sarana untuk pemisahan padatan dan pasir, sehingga semua benda padat yang terbawa dalam limbah akan masuk dalam ruang pompa.

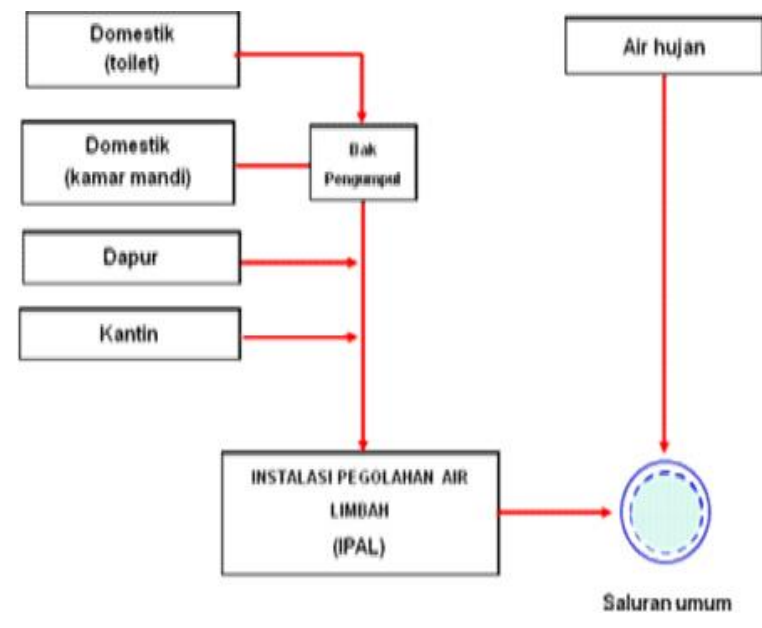

Gambar 2. Sistem Pengelolaan Limbah Cair Di RSUD Timika

Evaluasi :

Karena semua limbah feses, air dari kamar mandi dan lainnya dikumpulkan menjadi satu dan langsung masuk ke ruang pompa tanpa ada pengaman seperti ruang pemisah pasir dan pemisah padatan, maka banyak padatan dan pasir yang ikut masuk ke pompa. Dengan demikian akan mengakibatkan penyumbatan pompa, sehingga akan terjadi kemacetan di impeller pompa. Impeller pompa yang macet akan menimbulkan panas pada pompa dan mengakibatkan terbakarnya pompa.

Sistem pemasangan pompa juga langsung dengan stop kontak, tanpa ada panel pengaman dan tanpa ada indikator on/off dari pompa yang ada. Tanpa adanya panel pengaman ini akan menyebabkan sering terjadinya kebakaran pada pompa. Timika merupakan kota kecil dan belum banyak fasilitas atau pertokoan yang mempunyai berbagai usaha dan jauh dari kota besar. Jika ada permasalahan dengan pompa yang digunakan (terbakar), maka pihak pengelola akan kesulitan untuk melakukan penggantian dengan pompa yang baru atau melakukan service. Dengan demikian maka sebaiknya penggunaan pompa dan peralatan listrik lainnya diupayakan seminim mungkin.

Saat ini, hampir semua pompa yang terpasang dalam kondisi rusak, sehingga proses pengumpulan limbah tidak dapat berjalan dengan baik. Sistem bak pengumpul yang ada saat ini juga tidak dilengkapi dengan sistem over flow, yang akan menyalurkan limbah ke saluran 
drainase jika ada kerusakan pompa, sehingga saat ini hampir di semua bak pengumpul terjadi peluberan air limbah ke tanah di sekitarnya

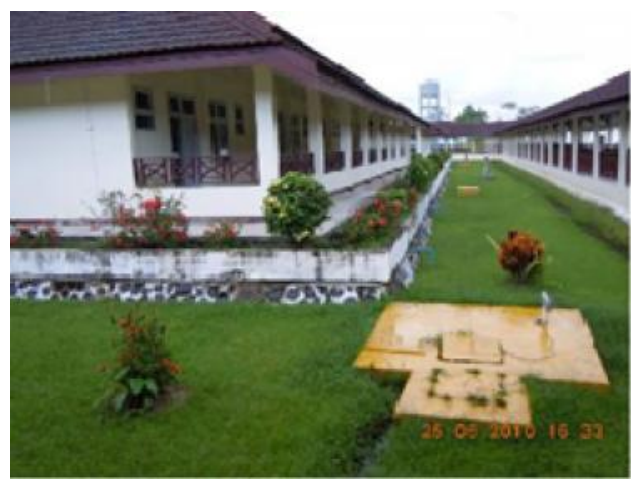

Gambar 3. Foto Kondisi Limbah Yang Mengalir Keluar Dari Dalam Bak Pengumpul

Dengan melubernya limbah di sekitar bak pengumpul ini, maka dikawatirkan limbah yang belum diolah ini akan mencemari air tanah di sekitar rumah sakit. Sementara itu sumber air bersih untuk keperluan RSUD menggunakan air tanah setempat. Hal ini sangat mengkawatirkan, karena sumber air bersih untuk keperluan RSUD menggunakan air tanah yang mempunyai resiko tercemar limbah domestik RSUD itu sendiri. Sementara sumber limbah yang ada tersebar di seluruh area RSUD, sehingga dikhawatirkan semua air tanah yang ada di sekitar lokasi akan terkena resiko pencemaran. Sumber-sumber limbah di RSUD ini seperti terlihat pada Gambar 4 pada lampiran.

\subsection{Proses Pengolahan Limbah di RSUD Timika Saat Ini}

Pengolahan limbah yang ada di RSUD Timika saat ini menggunakan sistem anaerob dilanjutkan dengan sistem wet land. Semua limbah yang dihasilkan dicampur menjadi satu, kemudian dipompa menuju ke IPAL. Dengan demikian maka feses dan semua limbah dari kamar mandi, laundry, dapur dan lainnya menyatu, kemudian dipompa dengan menggunakan jaringan perpipaan.

Dengan menyatunya semua limbah yang ada ini, maka resiko kerusakan pompa yang digunakan sangat besar. Hal ini telah terbukti, yaitu hampir semua pompa yang digunakan saat ini tidak dapat beroperasi. Disamping itu, kemungkinan resiko terjadinya penyumbatan di dalam pipa sangat besar, karena akan terjadi pengerakan yang diakibatkan oleh lemak dan minyak yang terbawa di dalam limbah.

Proses pengolahan di dalam IPAL dengan menggunakan sistem anaerobik dan reaktor biofilter menggunakan media biakan batu kali. Sementara limbah yang diolah di dalam IPAL ini adalah semua limbah yang dihasilkan di RSUD tanpa adanya septic tank didepannya, sehingga semua feses yang telah tercampur dengan air sabun/cucian dari laundry juga diolah bersama. Dengan proses anaerobik dan wet land saja, maka polutan limbah yang sedemikian berat (BOD, COD, TSS tinggi) akan sulit terdegradasi secara sempurna. Gambar 5 menunjukkan detail sistem pengolahan limbah yang ada di RSUD Timika. Sedangkan lay out IPAL seperti pada Gambar 6 pada lampiran.

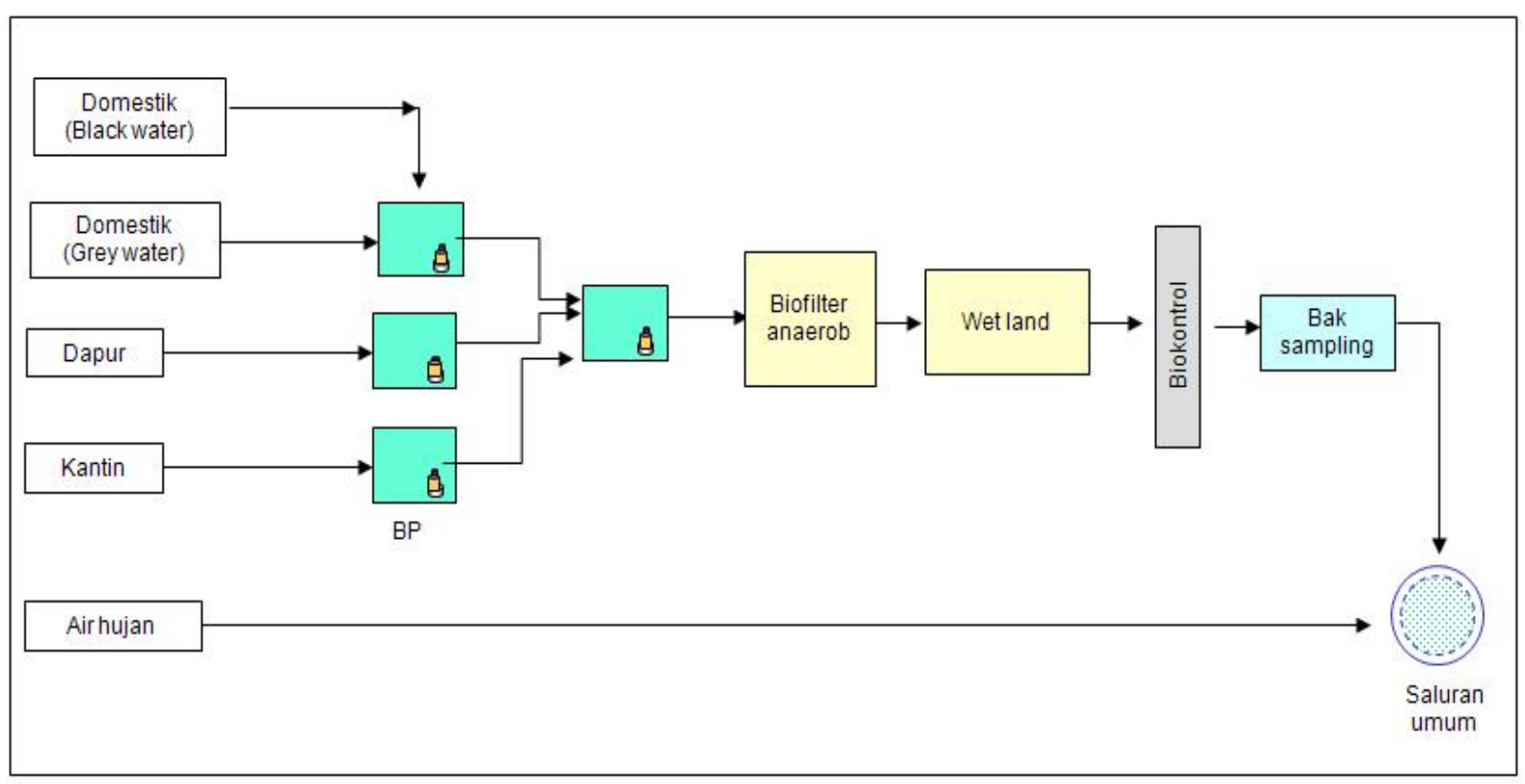

Gambar 5. Detail Sistem Pengolahan Limbah di RSUD Timika 
IPAL yang ada tidak dilengkapi dengan bak equalisasi, padahal bak equalisasi ini berperan sangat penting dalam meningkatkan efektivitas dari proses pengolahan selanjutnya. Tanpa adanya bak equalisasi ini, maka parameter operasional selanjutnya seperti flow dan kualitas polutan yang masuk ke IPAL tidak stabil. Pada saat pagi, siang dan sore hari dimana limbah dihasilkan dalam jumlah yang cukup besar, maka debit limbah akan besar sekali dan resiko terjadinya wash out dari mikroba yang ada di dalam sistem akan terjadi. Pada malam hari, dimana tidak ada limbah yang masuk, maka mikroba akan kekurangan suplai makanan. Dengan demikian, maka IPAL tidak akan dapat beroperasi dengan baik.

IPAL yang ada saat ini juga tidak dilengkapi dengan unit pemisah minyak. Sementara secara keseluruhan dari sistem pengumpulan limbah hanya ada satu unit bak pemisah minyak yang digunakan untuk memisahkan minyak dari limbah yang berasal dari dapur. Sementara sumber limbah dari ruang pasien dan sumber lainnya juga seringkali mengandung minyak meski dalam jumlah yang relatif lebih sedikit. Jika tidak ada sarana pemisah minyak dan lemak ini, maka kandungan minyak akan sangat mengganggu dalam proses selanjutnya, karena dapat menghambat transfer oksigen ke dalam sistem.

Proses pengolahan limbah cair di RSUD ini diawali pada unit bak pengendap awal (Gambar 7 pada lampiran). Di sini kotoran padat dan benda-benda lain yang terbawa dari sumber limbah diendapkan di bak pengendap ini. Volume total bak pengendap $24,8 \mathrm{~m}^{3}$. Jika kapasitas IPAL yang direncanakan $200 \mathrm{~m}^{3} /$ hari, maka waktu tinggal di bak pengendap adalah $24,8 \mathrm{~m}^{3}$ / $200 \mathrm{~m}^{3} /$ hari $\times 24$ (jam/hari) $=2,98$ jam. Waktu ini sudah cukup digunakan untuk mengendapkan kotoran yang terkandung di dalam limbah rumah sakit.

Selanjutnya air limbah masuk ke reaktor anaerobik melalui over flow bak pengendap. Reaktor anaerobik ini diisi dengan media tumbuh mikroba dari batu kali, seperti terlihat pada gambar 8 . Total volume media yang digunakan adalah $110 \mathrm{~m}^{3}$. Jika media batukali ini memiliki luas permukaan $100 \mathrm{~m}^{2} / \mathrm{m}^{3}$ media, maka luas permukaan media tumbuh mikroba yang ada sebesar $11.000 \mathrm{~m}^{2}$. Kemampuan degradasi reaktor anaerobik dengan luas permukaan sebesar $11.000 \mathrm{~m}^{2}$ ini maksimal hanya $40 \%$, sehingga BOD outlet dari reaktor masih sekitar $(240 \times 60 \%)=144$ ppm.

Setelah keluar dari reaktor anaerobik, limbah masuk ke wet land. Pada umumnya proses degradasi dengan sistem wet land ini hanya mampu mendegradasi limbah antara $5 \mathrm{~s} / \mathrm{d}$ $15 \%$, sehingga jika outlet dari reaktor anaerobik
144 ppm, maka BOD outlet limbah dari wet land (sistem IPAL) diperkirakan masih sekitar 122,4 ppm. Ini masih jauh di atas standar baku mutu kualitas limbah yang diijinkan.

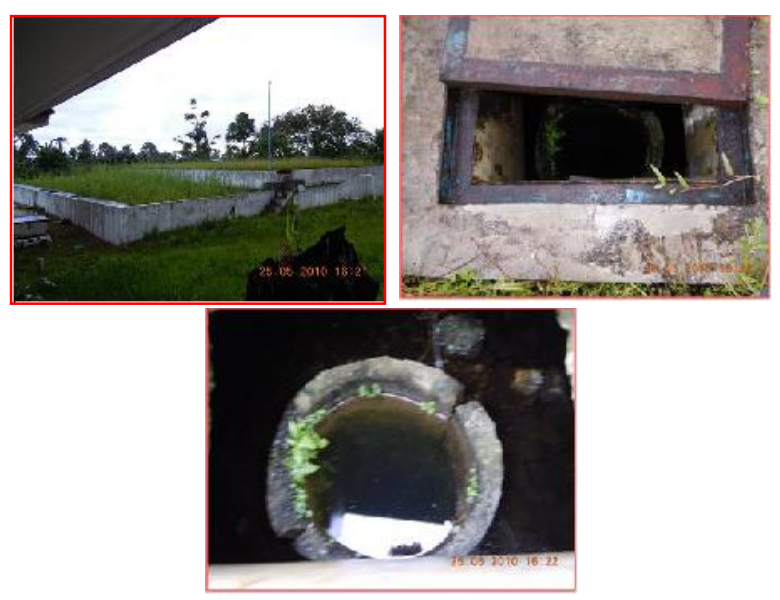

\section{Gambar 8. Foto IPAL Dan Media Tumbuh Mikroba Dengan Batuan}

\subsection{Revisi Sistem pengumpulan Limbah}

Sistem pengumpulan limbah di RSUD dengan pemompaan dirasa kurang tepat dan banyak menemui kendala (Gambar 9). Padahal RSUD Timika dibangun di lokasi yang mempunyai tingkat kemiringan area yang cukup besar, sehingga sistem pengumpulan limbah seharusnya dapat dilakukan dengan sistem perpipaan saja (gravitasi). Hal ini akan memudahkan dalam perawatan serta tidak memerlukan biaya listrik, perbaikan dan penggantian pompa. Dengan sistem ini biaya investasi, operasional dan perawatannya jauh lebih murah.

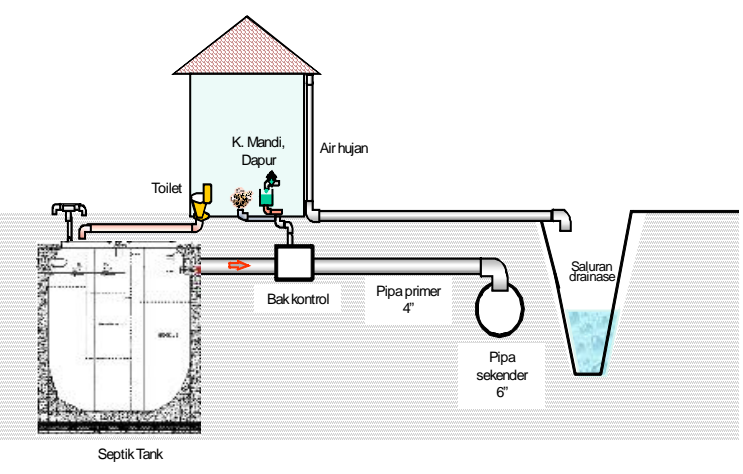

Gambar 9. Sistem Pengelolaan Limbah RSUD Timika Dengan Sistem Perpipaan Gravitasi

Karena banyaknya kendala pada sistem pengumpulan limbah dengan sistem pompa ini, maka direkomendasikan untuk menggantikan sistem pengumpulan limbah dengan sistem perpipaan dan seminimal mungkin menggunakan 
pompa. Pipa-pipa yang digunakan sebagai jalur pengumpulan limbah dipilih dari jenis PVC yang tahan terhadap karat, yaitu pipa primer dengan PVC kelas AW berdiameter 4", dan pipa sekunder dengan PVC kelas AW berdiameter 6".

Sistem jaringan air limbah yang direkomendasikan ini dilengkapi dengan septic tank. Ada berbagai pertimbangan dalam penambahan septic tank ini, antara lain :

- Karena septic tank merupakan sistem pengolahan limbah feses secara anaerobik yang sangat efektif. Dalam septic tank ini feses dapat terurai secara sempurna dengan proses anaerobik tanpa memerlukan energi untuk mendegradasinya. Jika feses ini tidak diolah terlebih dahulu pada septic tank, maka feses akan masuk ke IPAL bercampur dengan limbah dari laundry yang banyak mengandung deterjen. Jika hal ini terjadi, maka diperlukan energi yang cukup besar untuk mengolah limbah feses ini dan diperlukan sistem pengeluaran lumpur dari hasil degradasi feses ini secara kontinyu.

- Dengan septic tank ini, maka yang disalurkan ke IPAL terpusat hanya over flow dari septic tank saja, sehingga tidak ada padatan yang akan mengganggu dalam proses pengumpulan limbah di dalam pipa. Jika pengumpulan limbah diperlukan pemompaan, maka tidak ada feses yang mengganggu di impeller pompa.

- Dengan adanya septic tank, maka limbah yang dikumpulakan relatif lebih bersih dari pada tanpa septic tank, sehingga lebih memudahkan dalam perawatan sistem jaringan pengumpulan limbah.

- Dengan adanya septic tank, maka banyak padatan yang sulit terurai akan tertahan di dalam bak pengendap septic tank, sehingga saringan di setiap bak kontrol tidak sering tersumbat.

Dengan adanya perubahan sistem ini, maka ada beberapa tempat (sumber limbah) yang tidak memungkinkan dilakukan pengumpulan limbah dengan perpipaan gravitasi, sehingga akan dilakukan sistem pemompaan. Gambar 10 menunjukkan sistem pengumpulan menggunakan pemompaan. Perbedaan yang ada dengan sistem perpipaan secara langsung hanya di bak kontrol yang digantikan dengan bak pengumpul yang dilengkapi dengan pompa submersible (celup) outomatik.

Bak pengumpul ini dilengkapi dengan sistem pemisahan padatan yang berbentuk sekat di dalam bak. Secara rutin bak pengumpul ini harus dicek untuk melihat kondisi di ruang pertama apakah ada kotoran baik yang mengapung maupun yang mengendap di dasar bak. Jika ada kotoran/padatan yang tertampung dalam bak pertama ini, maka kotoran tersebut harus diambil untuk dibersihkan agar tidak mengganggu aliran alir limbah dan untuk menghindari terjadinya penyumbatan pada pompa di Bak Pengumpul (BP).

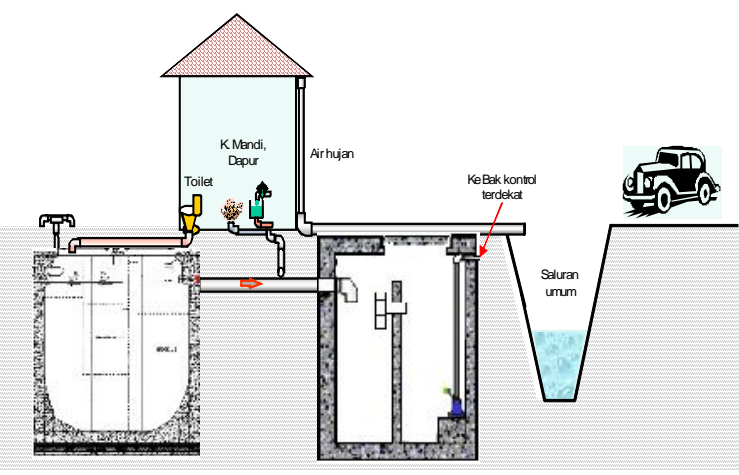

Gambar 10 Sistem Pengelolaan Limbah RSUD Timika Dengan Sistem Pemompaan

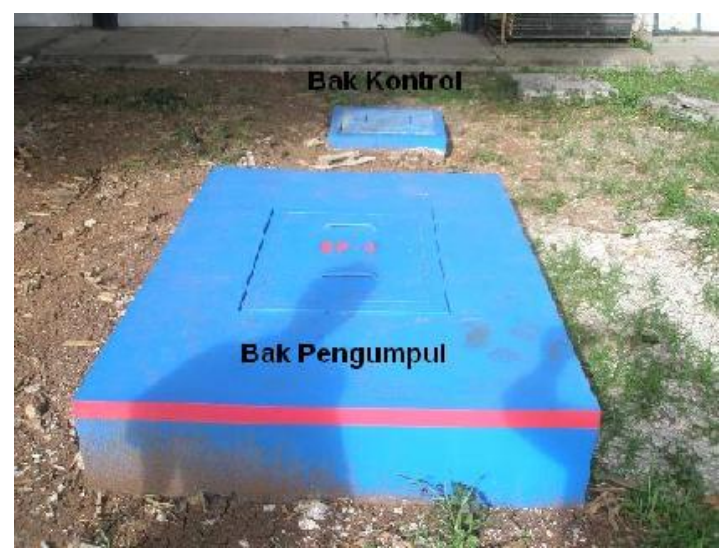

Gambar 11. Contoh Foto Bak Pengumpul Dan Bak Kontrol

Pemasangan pompa submersible dilengkapi dengan sock drat dan water more untuk mempermudah bongkar-pasang pompa jika terjadi kerusakan. Pipa penyalur yang digunakan dengan PVC kelas AW berdiameter 2". Disamping itu pipa penyaluran limbah juga dilengkapi cek valve untuk mencegah berbaliknya air limbah dalam pipa ke dalam bak pengumpul. Secara detail sistem pemasangan pompa di dalam bak pengumpul ini dapat dilihat seperti pada Gambar 12

Karena air limbah yang terkumpul di bak pengumpul ini merupakan air kotor yang masih banyak mengandung padatan, maka jenis pompa yang digunakan harus memenuhi persyaratan pompa air kotor dan tahan karat. Foto jenis pompa yang layak dan sering digunakan dapat dilihat pada Gambar 13. 


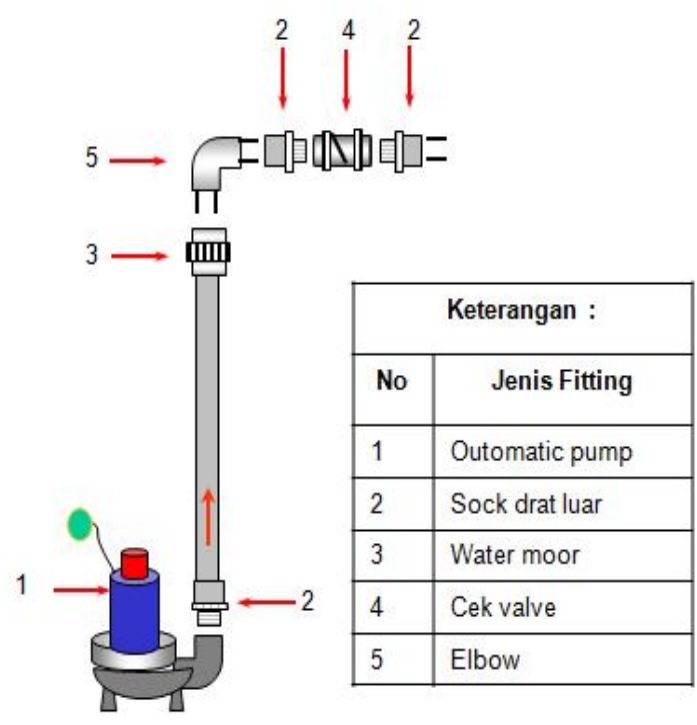

\section{Gambar 12. Pemasangan Pompa Celup Di} Dalam Bak Pengumpul

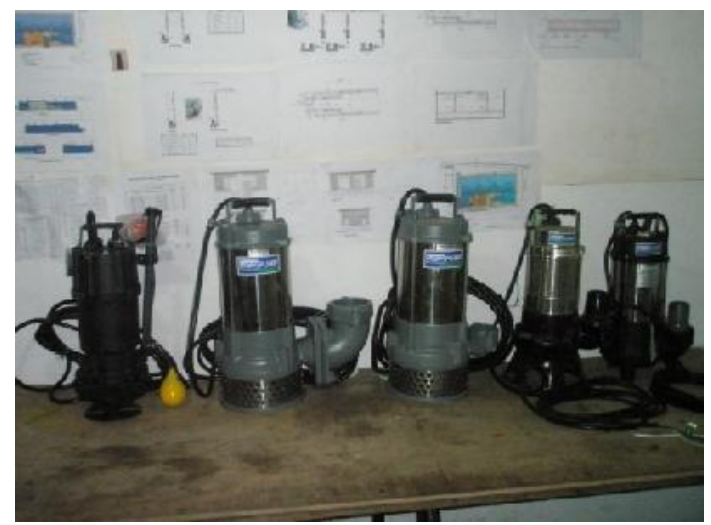

Gambar 13. Foto Jenis Pompa Yang Digunakan di IPAL dan BP

Secara detail, peta sistem pengumpulan limbah yang baru ini dapat dilihat pada lampiran 1.

\subsection{Pengolahan Limbah di RSUD Timika Yang Direkomendasikan}

\subsubsection{Pemilihan Teknologi}

Teknologi yang direkomendasikan untuk perbaikan adalah kombinasi Teknologi Biofilter Anaerob dan Aerob yang menggunakan media tipe sarang tawon untuk tempat melekat dan tumbuh mikroba. Teknologi ini adalah hasil pengembangan peneliti BPPT yang telah diuji dan diaplikasikan di banyak tempat untuk mengolah air limbah, khususnya air limbah organik seperti air limbah domestik. Beberapa keunggulan proses pengolahan air limbah domestik dengan sistem kombinasi proses biofilter Anaerob-Aerob adalah :
- Efisiensi penghilangan BOD, COD dan padatan tersuspensi (SS) sangat tinggi, yakni lebih dari $90 \%$.

- Pengelolaannya sangat mudah.

- Biaya operasionalnya rendah.

- Dibandingkan dengan proses lumpur aktif, lumpur yang dihasilkan relatif sedikit.

- Suplai udara untuk aerasi relatif kecil.

- Dapat digunakan untuk air limbah dengan beban BOD yang cukup besar.

- Tahan terhadap perubahan fluktuasi jumlah air limbah dan beban pengolahan secara mendadak.

\subsubsection{Proses Pengolahan}

\section{Bak Pemisah Minyak}

Bak pemisah selain dipasang di sumber limbah dari kantin, juga di pasang di lokasi terdepan dari IPAL. Hal itu karena limbah yang berasal dari ruang pasien maupun dari sumber lain juga sering kali mengandung minyak, meski dalam jumlah yang relatif kecil. Namun jika hal ini tidak diantisipasi, maka minyak dan lemak ini nantinya akan terakumulasi di bak equalisasi dan akan mengganggu dalam proses-proses berikutnya.

\section{Equalisasi}

Bak Equalisasi bukan merupakan suatu proses pengolahan tetapi merupakan suatu cara untuk meningkatkan efektivitas dari proses pengolahan selanjutnya. Keluaran dari bak equalisasi adalah parameter operasional bagi unit pengolahan selanjutnya yang akan lebih menjamin kestabilan kualitas maupun kuantitas limbah. Dalam bak equalisasi juga dilengkapi dengan proses pengadukan mekanik, yaitu dengan agitator atau dengan sistem sirkulasi pompa. Dari bak equalisasi ini, air limbah dipompa dan dengan gate valve dapat dilakukan pengaturan debit limbah yang akan masuk ke sistem IPAL, sehingga aliran limbah yang diolah ke dalam sistem IPAL akan berjalan secara kontinyu selama 24 jam dengan debit yang stabil dan beban polutan yang realtif stabil pula.

Kegunaan dari equalisasi adalah :

1. Mengkontinyukan debit limbah yang akan diolah di IPAL (membagi dan meratakan volume pasokan (influent) untuk masuk pada proses treatment.

2. Menstabilkan karakteristik limbah (meratakan variable) \& fluktuasi dari beban organik untuk menghindari shock loading pada sistem pengolahan biologi.

3. Meratakan $\mathrm{pH}$ untuk meminimalkan kebutuhan chemical pada proses netralisasi (jika diperlukan). 
4. Meratakan kandungan padatan (SS, koloidal, dil) untuk meminimalkan kebutuhan chemical pada proses koagulasi dan flokulasi (jika diperlukan).

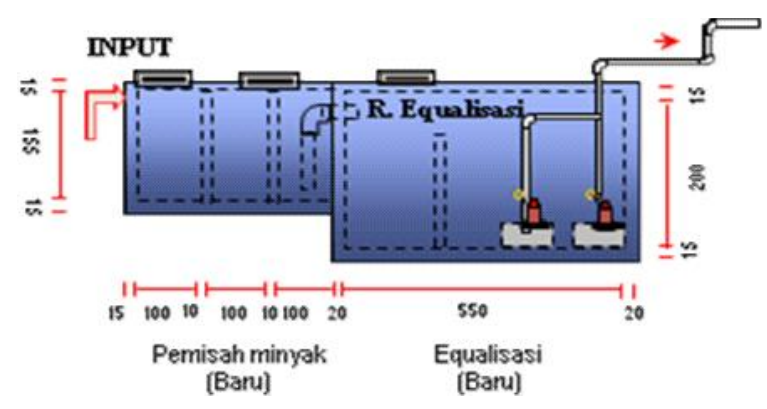

Gambar 14. Gambar Potongan Bak Equalisasi dan Pemisah Minyak

Air limbah dari seluruh rumah sakit dikumpulkan dengan sistem perpipaan menuju ke bak equalisasi yang didepannya telah dilengkapi dengan bak pemisah minyak/lemak. Bak pemisah lemak tersebut berfungsi untuk memisahkan lemak atau minyak serta untuk mengendapkan kotoran pasir, tanah atau senyawa padatan yang tak dapat terurai secara biologis, misalnya abu gosok, padatan pembersih kamar mandi dll. Dari bak equalisasi selanjutnya limbah yang telah terbebas dari lemak dan minyak dipompa ke bak pengurai anaerob.

\section{Reaktor Biofilter}

Bak pengurai (reaktor) anaerob ini akan menggunakan reaktor anaerobik yang ada saat ini, namun karena kapasitasnya tidak memenuhi dengan perencanaan rumah sakit, maka akan ditambahkan dengan reaktor anaerobik lanjutan (baru) dengan menggunakan media tumbuh mikroba sarang tawon yang lebih efisien. Proses sistem aliran yang ada tidak mengalami perubahan, dan setelah keluar dari reaktor anaerobik IPAL yang lama, limbah akan dialirkan menuju reaktor anaerobik yang baru. Untuk itu maka disain reaktor yang baru ini setting ketinggiannya harus menyesuaikan dengan IPAL lama.

Air limpasan dari reaktor anaerob dialirkan ke unit pengolahan lanjut. Unit pengolahan lanjut tersebut terdiri dari beberapa buah ruangan yang berisi media sarang tawon untuk pembiakan mikro-organisme yang akan menguraikan senyawa polutan yang ada di dalam air limbah. Penguraian zat-zat organik yang ada dalam air limbah dilakukan oleh bakteri anaerobik atau fakultatif aerobik. Setelah beberapa hari operasi, pada permukaan media filter akan tumbuh lapisan film mikro-organisme.
Mikro-organisme inilah yang akan menguraikan zat organik yang belum sempat terurai pada bak pengendap.

Air limpasan dari bak kontaktor anaerob dialirkan ke bak kontaktor aerob. Di dalam bak kontaktor aerob ini diisi dengan media sarang tawon, sambil diaerasi sehingga mikro organisme yang ada akan menguraikan zat organik yang ada dalam air limbah serta tumbuh dan menempel pada permukaan media. Dengan demikian air limbah akan kontak dengan mikroorgainisme yang tersuspensi dalam air maupun yang menempel pada permukaan media. Hal tersebut dapat meningkatkan efisiensi penguraian zat organik, deterjen serta mempercepat proses nitrifikasi, sehingga efisiensi penghilangan ammonia menjadi lebih besar.

Dari bak aerasi, air dialirkan ke bak pengendap akhir. Di dalam bak ini lumpur aktif yang mengandung massa mikro-organisme diendapkan dan dipompa kembali ke bagian inlet bak aerasi dengan pompa sirkulasi lumpur. Sedangkan air limpasan (over flow) dialirkan ke bak khlorinasi. Di dalam bak kontaktor khlor ini air limbah dikontakkan dengan senyawa khlor untuk membunuh micro-organisme patogen. Air olahan, yakni air yang keluar setelah proses khlorinasi dapat langsung dibuang ke sungai atau saluran umum. Skema proses pengolahan air limbah RSUD Timika dengan sistem biofilter anaerob-aerob dapat dilihat pada Gambar 15 pada lampiran.

\subsubsection{Media Biofilter}

Media biofilter sarang tawon termasuk hal yang penting, karena media ini berfungsi sebagai tempat tumbuh dan menempelnya mikroorganisme. Dua sifat yang paling penting yang harus ada dari media adalah :

- Luas permukaan dari media yang cukup besar per satuan volume.

- Persentase ruang kosong yang baik, karena semakin besar ruang kosong, akan semakin besar pula kontak biomassa yang menempel pada media pendukung dengan substrat yang ada dalam air buangan.

Untuk mendapatkan permukaan media yang luas, media dapat dimodifikasikan dalam berbagai bentuk, yaitu bergelombang, saling silang seperti sarang tawon.

Salah Satu contoh media biofilter yang banyak digunakan, yakni media dalam bentuk sarang tawon (honeycomb tube) dari bahan PVC. Kelebihan dalam menggunakan media plastik tersebut antara lain :

- Mempunyai luas permukaan per $\mathrm{m}^{3}$ volume sebesar $150-240 \mathrm{~m}^{2} / \mathrm{m}^{3}$ 
- Volume rongga yang besar dibanding media lainnya.

- Kemungkinan terjadinya penyumbatan pada media sangat kecil (4).

Gambar 16 menunjukkan media sarang tawon yang telah banyak digunakan.

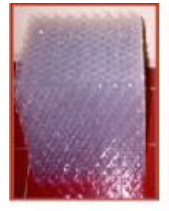

Media Eau

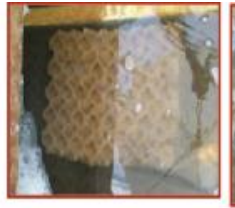

Media di Dalam
Reaktor

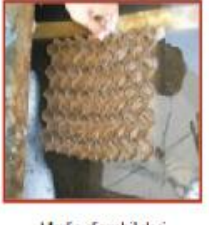

Media diambil dari
Reaklor

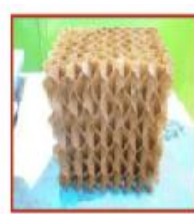

Meda dikeluarkan cai
Reaktor
Gambar 16. Foto Sarang Tawon

\section{KESIMPULAN}

Berdasarkan hasil evaluasi dan redisain IPAL RSUD Timika tersebut di atas, maka dapat ditarik beberapa kesimpulan, antara lain :

- Sistem pemompaan kurang sesuai digunakan untuk pengumpulan limbah di RSUD Timika.

- Karena kontur lokasi rumah sakit mempunyai kemiringan yang cukup, maka pengumpulan limbah lebih sesuai dilakukan dengan menggunakan sistem gravitasi dengan pipa tertutup.

- IPAL yang saat ini tidak dapat beroperasi, dapat dimanfaatkan kembali dengan melakukan modifikasi terlebih dahulu.

- Modifikasi IPAL ini lebih tepat dengan menggunakan teknologi biofilter dengan proses anaerobik dan aerobik.

\section{DAFTAR PUSTAKA}

1. ----, "Pekerjaan Penentuan Standard Kualitas Air Limbah Yang Boleh Masuk Ke Dalam Sistem Sewerage PD PAL JAYA", Dwikarsa Envacotama-PD PAL JAYA, 1995.

2. Adriaens, P., Kohler, HP.E, Kohler-Staub, D., and Focht, D.D. (1989). Bacterial dehalogenation of Chlorobenzoates and coculture biodegradation of 4,4dichlorobiphenyl. Appl. Environ. Microbiol. 5:887-892.

3. Meneg LH, Kep. Meneg LH Nomor : KEP.58/MENLH / 12/1995, tentang Baku Mutu Limbah Cair Kegiatan Rumah Sakit, tanggal 12 Desember 1995.

4. Said, N.I, , "Pengolahan Air Limbah Domestik di DKI Jakarta", Pusat Teknologi Lingkungan, Deputi Bidang Teknologi Pengembangan Sumberdaya Alam, Badan Pengkajian dan Penerapan Teknologi, 2008.

5. Said, N.I, "Paket Teknologi Pengolahan Air Limbah Rumah Sakit Yang Murah dan Efisien", Jurnal Air Indonesia, Vol. 2, No. 1, Jakarta, 2006.

6. Suffet, I.H. Fate of Pollutants in the Air and Water Environments. Volume 8, Part 1, "Mechanism of interaction between environments and mathematical modeling and the physical fate of pollutants, Advances in Environmental Science and Technology, John Wiley \& Sons, A Wiley-Interscience Publications, New York, USA, 1977. 


\section{LAMPIRAN 1}

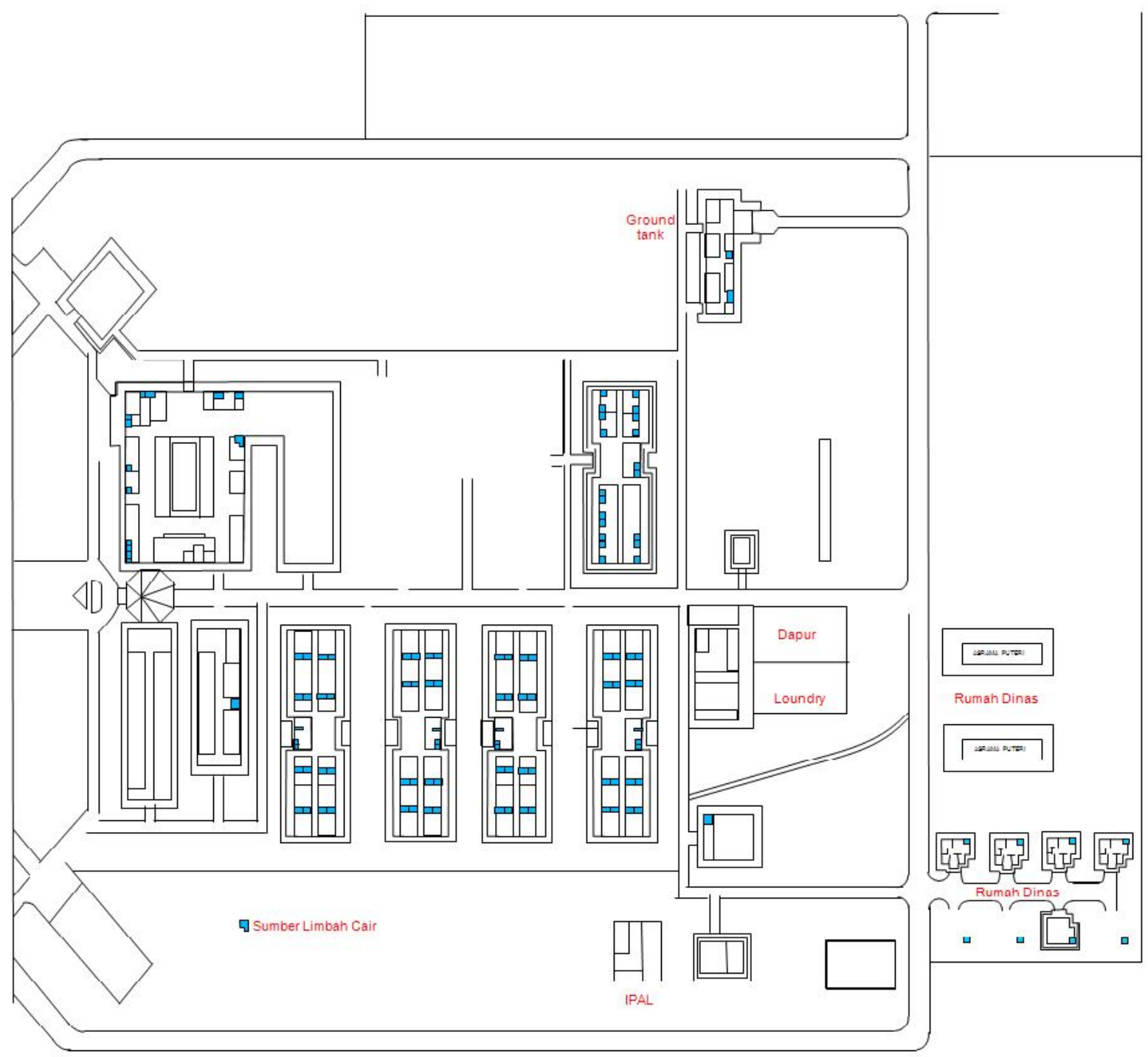

Gambar 4. Denah Pemetaan Sumber Limbah RSUD Timika

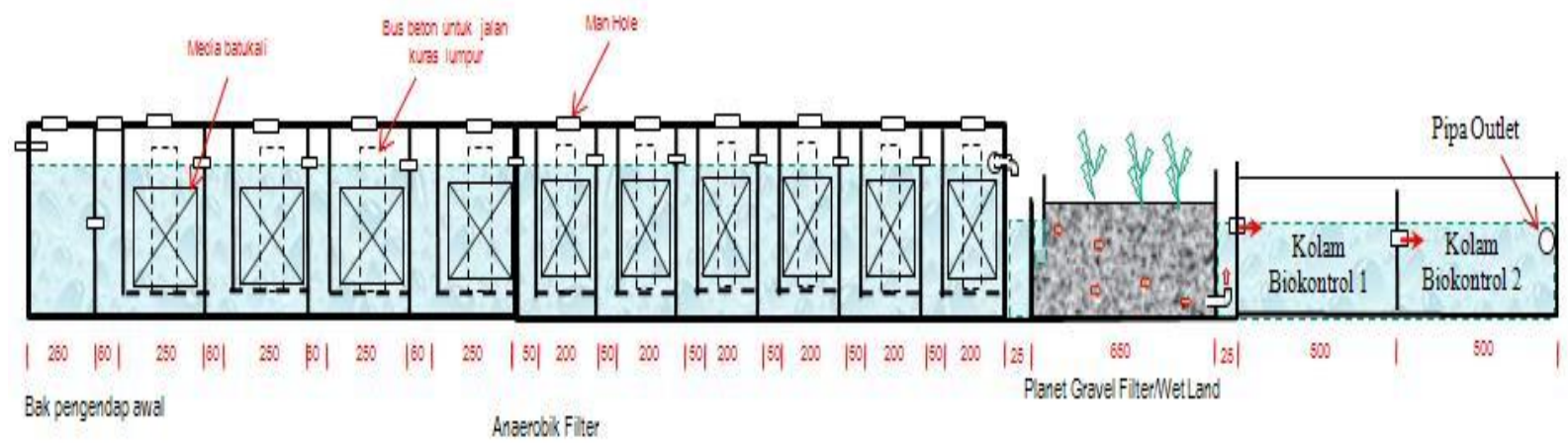

Gambar 7. Proses IPAL di RSUD Timika 


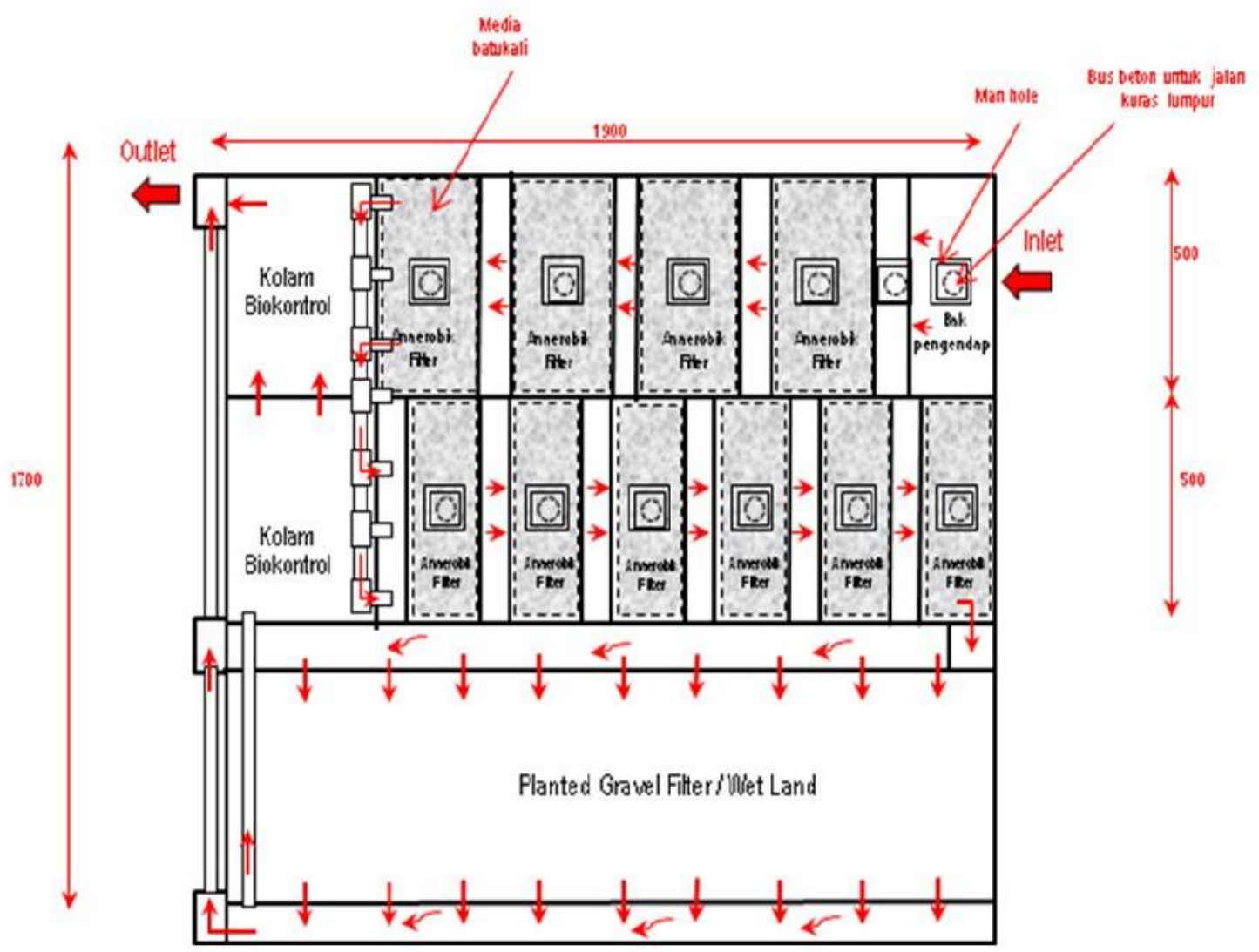

Gambar 6. Lay out IPAL di RSUD Timika

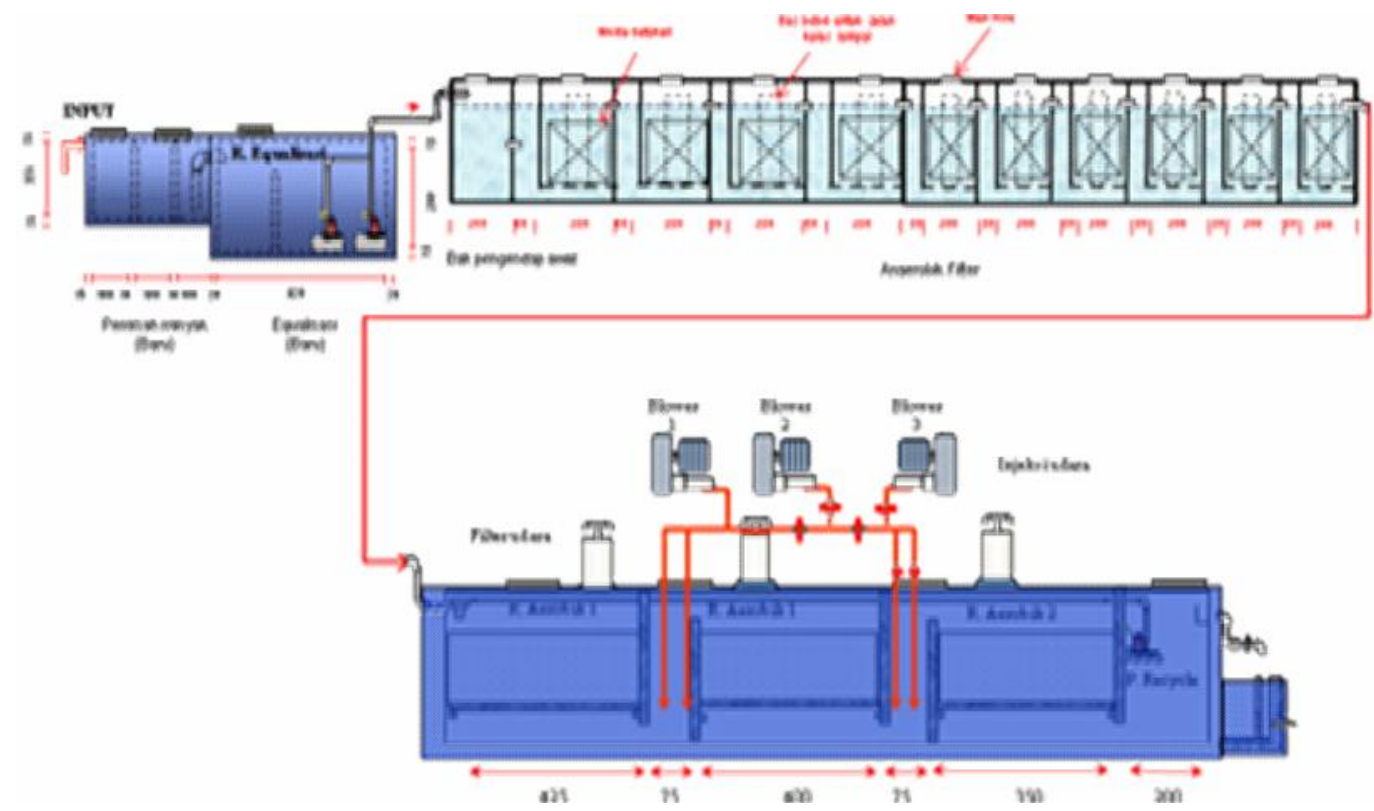

Gambar 15. Diagram Proses Modifikasi IPAL RSUD Timika, Dengan Proses Biofilter Anaerob-Aerob 


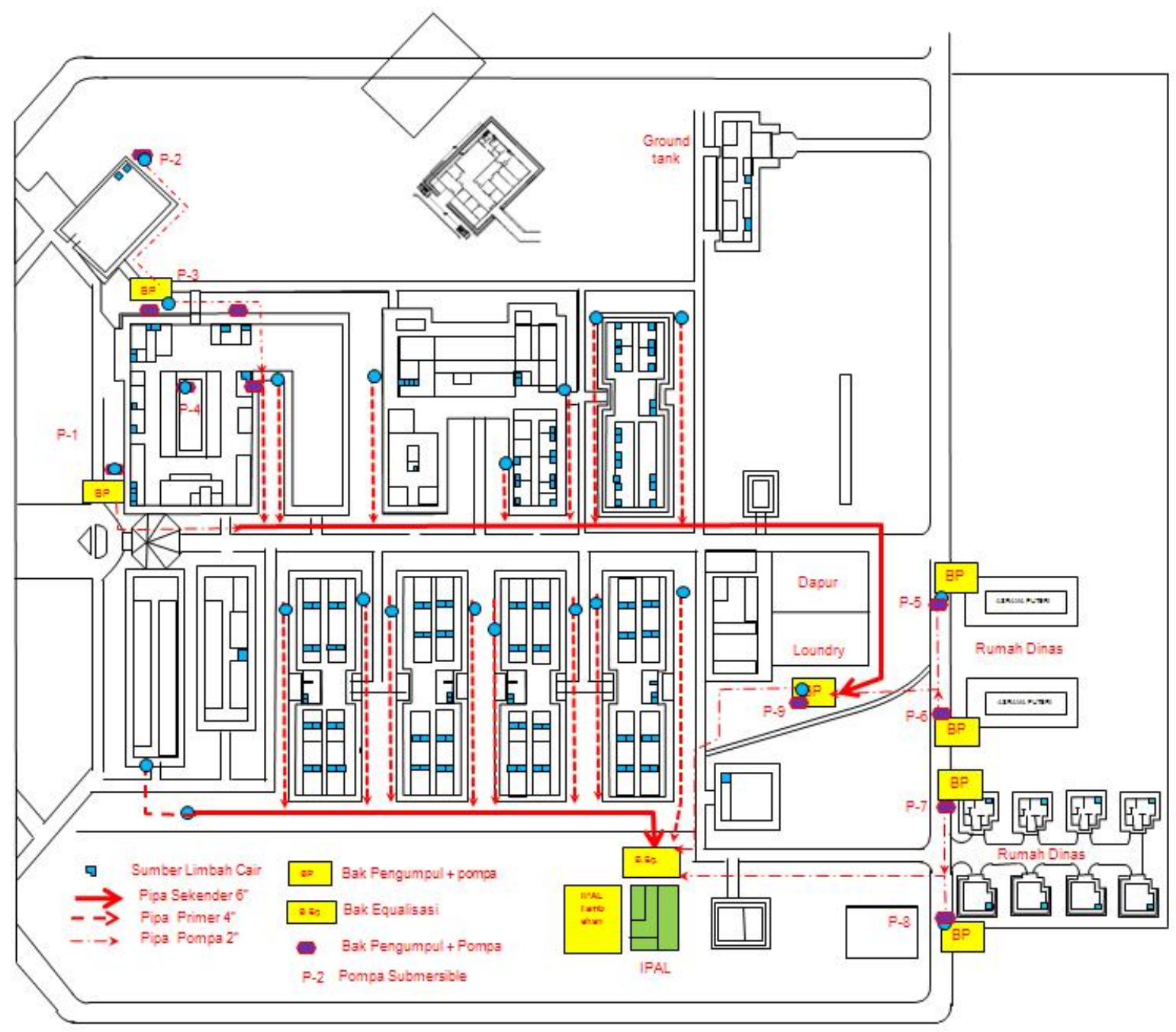

Gambar 17. Peta Jaringan Pengumpulan Limbah Dengan Sistem Gravitasi 